\title{
Genetic variation of striped snakehead (Channa striatus Bloch, 1793) populations using random amplified polymorphic DNA (RAPD) markers
}

\author{
Ajaz Ali Bhat ${ }^{1}$, M. A. Haniffa ${ }^{1 *}$, M. James Milton ${ }^{1}$, Bilal Ahmad Paray ${ }^{1}$, P. R. Divya ${ }^{2}$ and \\ A. Gopalakrishnan ${ }^{2}$ \\ ${ }^{1}$ Centre for Aquaculture Research and Extension, St. Xavier's College, Palayamkottai Tamilnadu-627 002, India. \\ ${ }^{2}$ National Bureau of Fish Genetic Resources (NBFGR), Cochin Unit, CMFRI Campus, Kochi- 682 018, India.
}

Receive 02 November, 2013; Accepted 15 April, 2014

\begin{abstract}
Random amplified polymorphic DNA-polymerase chain reaction (RAPD-PCR) was applied to analyze the genetic variation among Channa striatus collected from four geographically distant locations in India. After initial PCR screening, nine random oligodecamers viz. OPA10, OPA11, OPA15, OPAC01, OPAC03, OPAC05, OPAC07, OPAC09 and OPAC19 which generated the RAPD profile for the four C. striatus populations were selected. Amplification using these nine primers resulted in fragments ranging in length between 309-3029 bp assigned to 87 loci. Estimates of Nei's (1978) unbiased genetic distance (D) values ranged from $0.3242-0.6320$. Unweighted pair group method with arithmetic mean (UPGMA) dendrogram constructed on the basis of genetic distance revealed very close genetic relationship among C. striatus populations of river Tamirabarani (Tamil Nadu) and river Periyar (Kerala). Both populations from river Tamirabarani and Periyar were found to be genetically closer to fish populations from Kolleru Lake (Andhra Pradesh) whereas C. striatus population from Brahmani River (Orissa) was found to be genetically distant from the rest of the populations.
\end{abstract}

Key words: Indian snakehead, Channa striatus, genetic diversity, random amplified polymorphic DNA (RAPD).

\section{INTRODUCTION}

Murrels commonly called snakeheads belonging to genus Channa comprise one of the most important groups of freshwater food fish in tropical Asia (Benziger et al., 2011) having a wide natural distribution extending across the continent from Iran in the West, to China in the East, and parts of Siberia in the Far East (Berra, 2007). They are one of the most common staple food fish in Thailand,
Cambodia, Vietnam and other South East Asian countries where they are extensively cultured (Sinh and Pomeroy, 2010). Murrels are characterized by elongated body, round caudal fin, elongated dorsal and anal fins which are supported only by rays, large scales on their heads and dorso lateral position of eyes on the anterior part of the head (Figures 1 and 2). Scales are cycloid or 


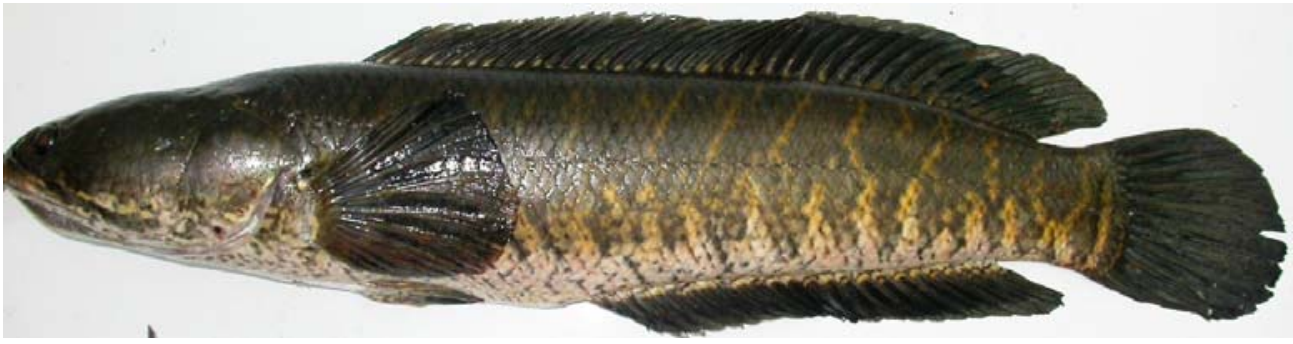

Figure 1. Elongated body of Channa striatus.
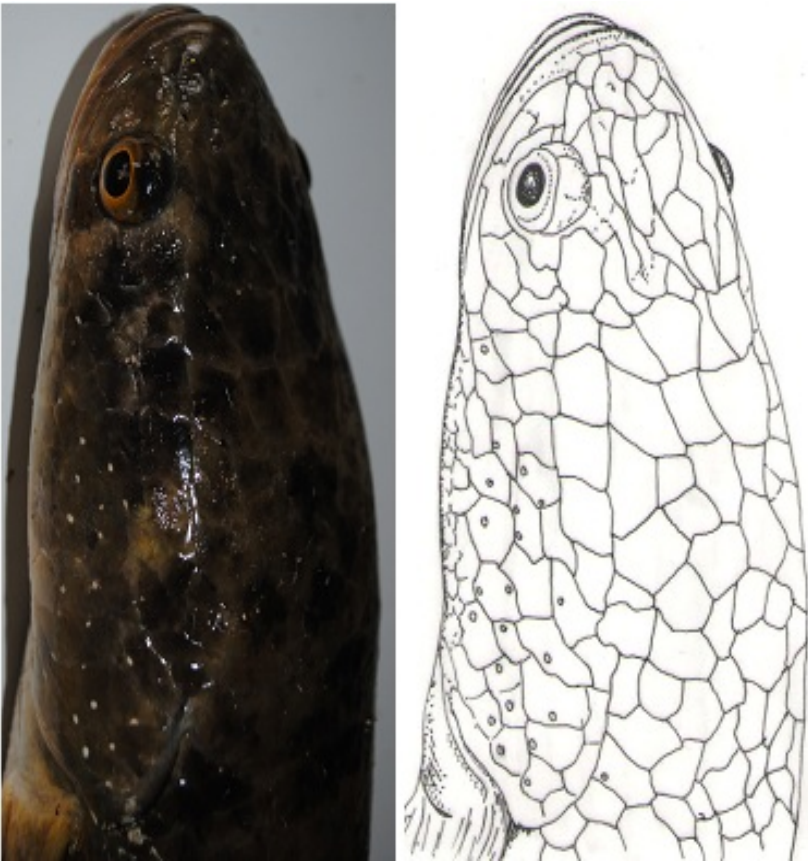

Figure 2. Presence of large scales on head and dorso lateral position of eyes of snakehead.

ctenoid (Musikasinthorn, 1998, 2003). The mouth is terminal and large with a protruding lower jaw, which is toothed, often containing canine-like teeth. Murrels can also be distinguished based on coloration, meristic, morphometric characteristics, distribution of scales on the underside of the lower jaw, the shape of the head and the morphology of the supra branchial organs.

Channa striatus is commonly called Chevron snakehead, striped murrel or striated murrel and is one of the most economically important Channid species inhabiting freshwater as well as brackishwater (Bloch, 1793). C. striatus displays dramatic colour changes (Haniffa et al., 2013) between early, late juvenile and adult stage as the hatchlings are black followed by a critical red color stage from post hatchling to fry, again turn black during fingerling stage and finally the adults show white striations all over the body (Figure 3).

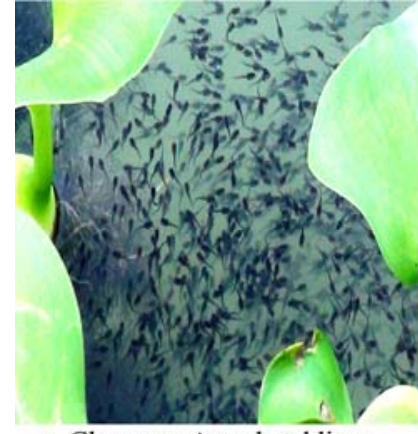

a. Channa striatus hatchlings

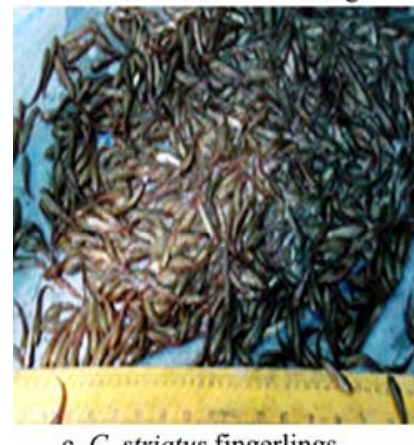

c. C. striatus fingerlings

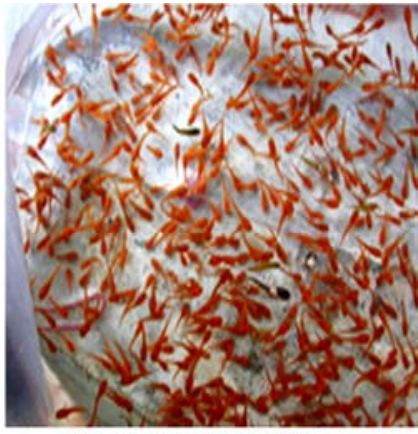

b. Channa striatus fry

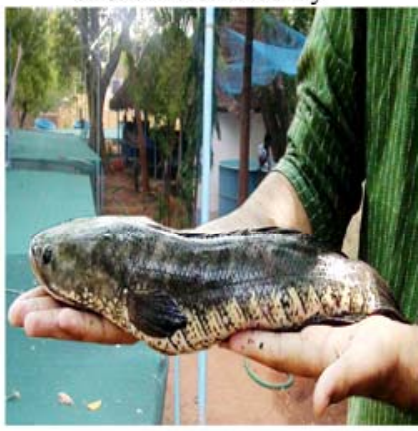

d. C. striatus adult
Figure 3. Color variations shown by $C$. striatus during life stages.

This Channid species is regarded as highly prized food fish in Asia (Hossain et al., 2008; Haniffa, 2010) and is ubiquitous and abundant throughout India. C. striatus possesses peculiar characteristics like air breathing ability, hardiness and high tolerance to adverse environmental conditions and the medicinal properties make it suitable for post surgical, convalescence and arthritis patients (Ali, 1999; Mat Jais et al., 2009). Morphologically, the body is cylindrical, elongated dorsal and anal fins supported by rays only, plate like scales on head and a round caudal fin (Xia, 2006; Bhat et al., 2012). Upper body pigmentation is greenish brown to almost black; oblique bars/stripes give the impression of forward facing $V$ shaped pattern consisting of dark streaks and blotches.

The earlier studies presented various meristic and morphometric characters like dorsal fin rays $42-45$, anal 
fin rays $26-29$, lateral line scales $55-65$, large mouth with lower jaw having 4-7 canines behind a single row of villiform teeth, dorsal and anal fins slightly darker in color than the maxilla and premaxillary process extending to vertical level beyond posterior margin of orbit, presence of a sharp pointed ridge at the mid-ventral part of isthamus and anterior to it many longitudinal striae are present; total vertebrae count 54 and branchial tooth plate count 13 (Vishwanath and Getakumari 2009). According to Nelson (1994), this group of teleostean fishes known as snakeheads is classified as:

\section{Class: Actinopterygii \\ Subclass: Neopterygii \\ Order: Perciformis \\ Suborder: Channoidei \\ Family: Channidae}

Genetic relationship between populations has been studied in different fish species having enormous evolutionary significance with regard to local adaptation, micro-evolutionary changes and maintenance of genetic variation (Slatkin, 1987). In finite populations, drift may lead to a loss of genetic variability in neutral markers which is usually applied in population studies, as well as allele compositional functional loci. Heterozygosity yields fitness advantage (Mitton, 1994) whereas loss of genetic variation will lead to reduced heterozygosity and ultimately lower fitness.

Random amplified polymorphic DNA (RAPD) is a simple and quick PCR-based technique, which uses arbitrary primers for amplification of discrete regions of genome (Williams et al., 1990) and most importantly, no prior knowledge of the genetic make-up of the organism is required (Hadrys et al., 1992).

RAPD markers have been used to evaluate the genetic diversity and conser-vation of numerous fish populations (Almeida et al., 2001, 2003; Dergam et al., 2002). The present investigations deals with genetic variation among four geographically distant populations of $C$. striatus collected from different Indian water bodies by RAPDPCR.

\section{MATERIALS AND METHODS}

\section{Sample collection}

The C. striatus samples were collected from Kolleru lake, Andhra Pradesh $\left(16^{\circ} 30^{\prime} \mathrm{N}\right.$ and $\left.81^{\circ} 15^{\prime} \mathrm{E}\right)$, River Periyar, Kerala $\left(10^{\circ} 10^{\prime} \mathrm{N}\right.$ and $\left.76^{\circ} 13^{\prime} \mathrm{E}\right)$, Brahmani River, Orissa $\left(22^{\circ} 48^{\prime} \mathrm{N}\right.$ and $\left.84^{\circ} 14^{\prime} \mathrm{E}\right)$ and River Tamirabarani, Tamil Nadu ( $80^{\circ} 44^{\prime} \mathrm{N}$ and $77^{\circ} 44^{\prime} \mathrm{E}$ ) (Figure 4).

\section{DNA isolation}

Approximately $100 \mathrm{mg}$ of fin tissue from 18 individuals of each population was preserved in $95 \%$ ethanol. DNA was isolated from preserved samples following Ruzzante et al. (1996) with minor

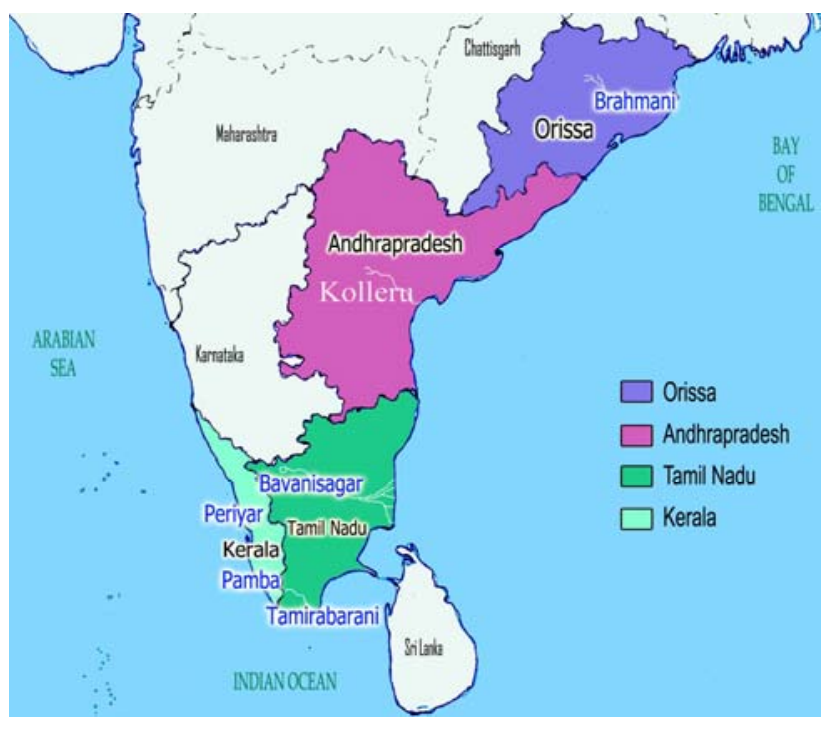

Figure 4. Map showing the collection sites of samples for the analysis of stock structure of $C$. striatus.

modifications.

\section{Screening of primers and PCR amplification}

A total of 30 arbitrary primers (OPAC and OPA series Operon Technologies Ltd. USA) with random sequence were screened (Nagarajan et al., 2006). Nine primers OPA10, OPA11, OPA15, OPAC01, OPAC03, OPAC05, OPAC07, OPAC09 and OPAC19 which gave reproducible results were selected. The PCR amplifications were carried out using Veriti 96 well Thermal Cycler Applied Biosystems in a reaction volume of $25 \mu$ l containing $50 \mathrm{ng}$ genomic DNA, 10X PCR buffer (10 mM Tris-HCLpH 9.0, $50 \mathrm{mM}$ $\mathrm{KCl}$ and $0.01 \%$ gelatin), $2.5 \mathrm{mM}$ of each dNTP, $5 \mathrm{pmol}$ of primer and 0.7 units of Taq DNA polymerase. The amplification conditions were $94^{\circ} \mathrm{C}$ for $5 \mathrm{~min}$ followed by 29 cycles at $94^{\circ} \mathrm{C}$ for $1 \mathrm{~min} .40^{\circ} \mathrm{C}$ for $1 \mathrm{~min}$ and $72^{\circ} \mathrm{C}$ for $2 \mathrm{~min}$ with a final extension at $72^{\circ} \mathrm{C}$ for 10 min.

\section{Agarose gel electrophoresis and visualization of bands}

After amplification $8 \mu \mathrm{l}$ of PCR products were electrophoresed in $1.5 \%$ agarose gel containing ethidium bromide and $1 \mathrm{X}$ TBE buffer to visualize the band patterns generated by each primer. The molecular weight of each band was estimated using a standard molecular marker (Lambda DNA/Eco RI Hind III Double Digest) with Image master 1D Elite Ver.3.01 (GE Amersham Biosciences USA) (Saini et al., 2010).

\section{Statistical analysis and dendrogram}

Statistical analysis was carried out for the RAPD band pattern of all the four $C$. striatus populations used for the present study. Using eight selected arbitrary primers viz, OPA10, OPA11, OPA15, OPAC01, OPAC03, OPAC05, OPAC07, OPAC09 and OPAC19, the molecular characterization of $C$. striatus populations and comparative analysis were made. RAPD band pattern was visually analyzed and scored from photographs. The well defined, prominent, 


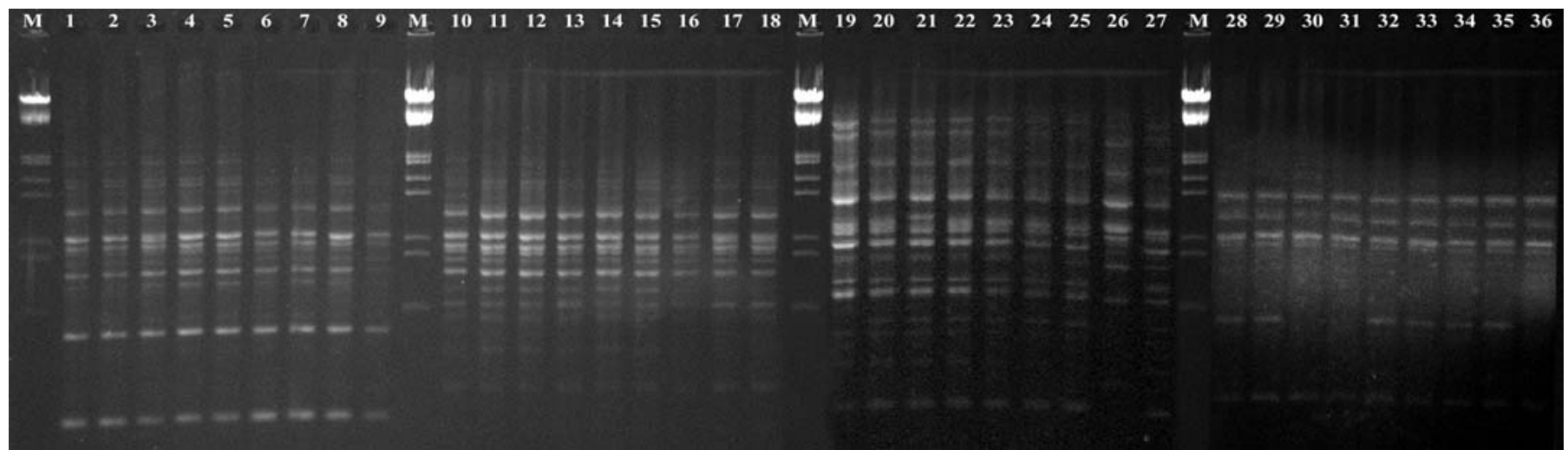

Figure 5. RAPD bands amplified by primer OPA-10 in four Channa striatus populations collected from various Indian locations (Lane M standard molecular weight marker; lanes 1 to 9 - Kolleru population; lanes 10 to 18- Periyar population; lanes 19 to $27-$ Brahamani population and lanes 28 to 36 - Tamirabarani population.

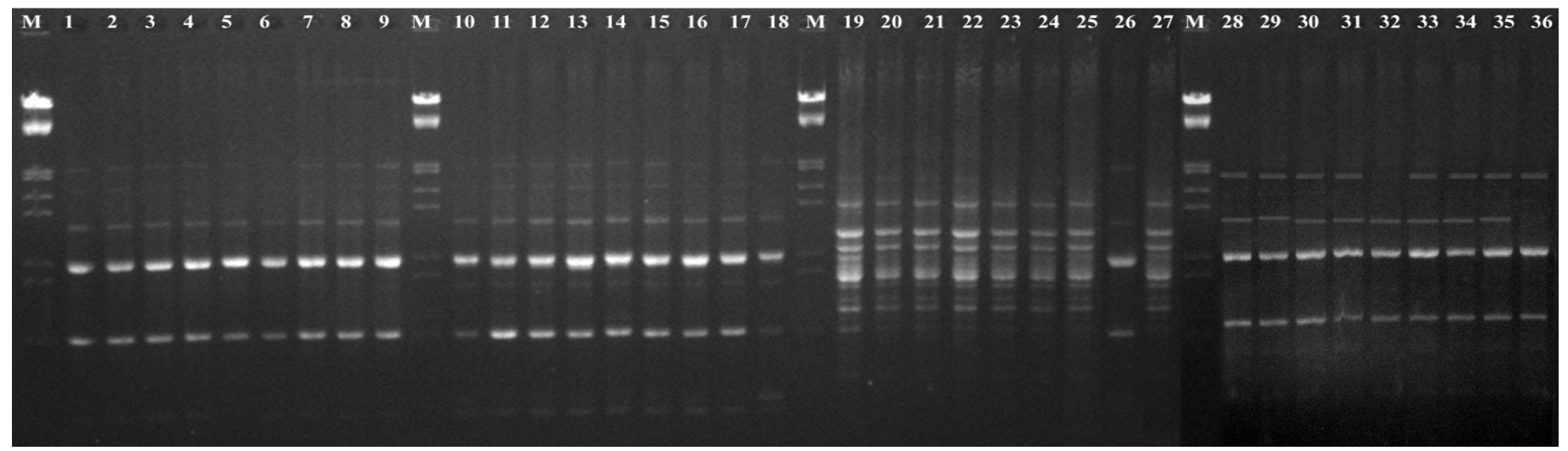

Figure 6. RAPD bands amplified by primer OPA-11 in four Channa striatus populations collected from various Indian locations. (Lane M standard molecular weight marker; lanes 1 to 9 - Kolleru population; lanes 10 to 18- Periyar population; lanes 19 to 27 - Brahamani population and lanes 28 to 36 - Tamirabarani population.

distinct and well separated bands were selected for the comparative analysis. The genotypes were determined by recording the presence (1) or absence (0) of the bands and neglecting the weak and unresolved bands. Nei's (1978) unbiased genetic identity (I) and genetic distance (D) values between $C$. striatus populations were calculated using the data generated from RAPD profiles using POPGENE 1.31 (Yeh et al., 1999). Genetic distance values were utilized to construct a dendrogram through clustering analysis (UPGMA) to determine the relationship between $C$. striatus populations.

\section{RESULTS AND DISCUSSION}

Out of 30 decamer primers screened 9 primers viz, OPA10, OPA11, OPA15, OPAC01, OPAC03, OPAC05, OPAC07, OPAC09 and OPAC19 showed reproducible results with good resolutions in banding patterns whereas the other 21 primers produced highly inconsistent amplification products or did not amplify at all and hence they were excluded from further analysis. The RAPD band profile for four geographically distant C. striatus populations for various selected oligodecamers are depicted in Figures 5 to 13 . The nine oligodecamer primers that generated amplification fragments ranging in length between 309-3029 bp in length were assigned to 87 loci. The number of stable and clear RAPD bands generated per primer varied between 5 and 13. The performance of Operon random primers on $C$. striatus populations collected from different Indian water systems which highlight the primer code, number of bands amplified, number of polymorphic bands, number of unique (monomorphic) bands and polymorphism percentage is shown in Table 1.

The RAPD amplification observed for the four different populations with the oligodecamers highlighted were consistent and showed population specific bands. Of the 87 RAPD bands, 11 were population-specific bands (unique bands) among the eleven population-specific bands, the Kolleru population had four bands, Periyar 


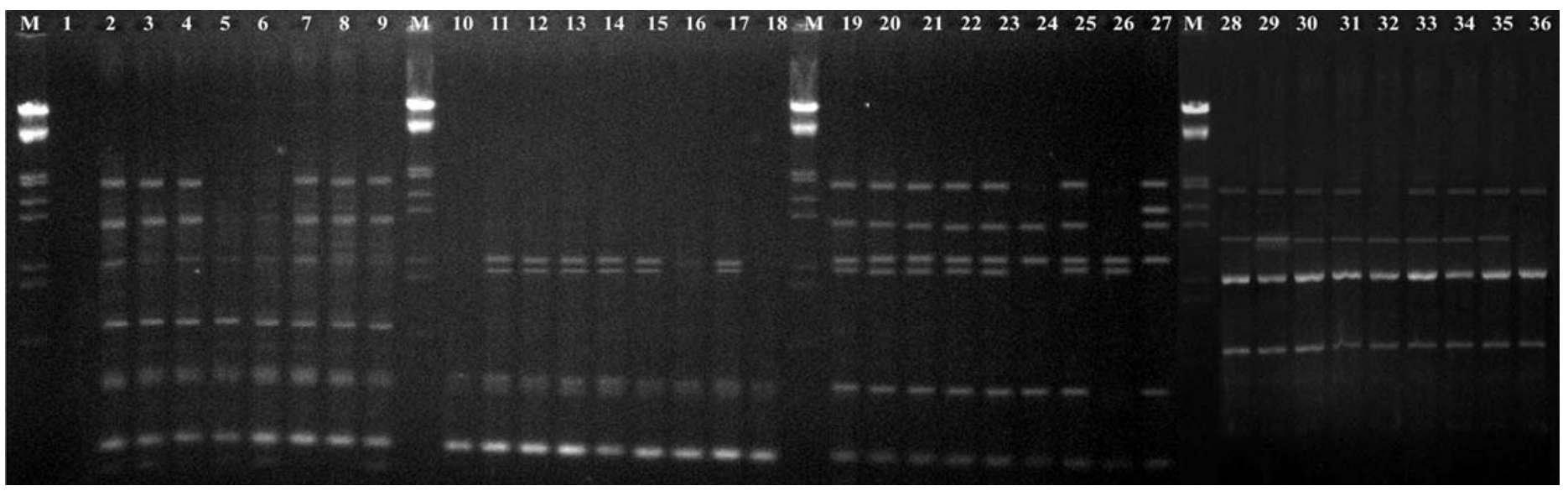

Figure 7. RAPD bands amplified by primer OPA-15 in four Channa striatus populations collected from various Indian locations. Lane M standard molecular weight marker; lanes 1 to 9 - Kolleru population; lanes 10 to 18 - Periyar population; lanes 19 to 27 - Brahamani population and lanes 28 to 36 - Tamirabarani population.

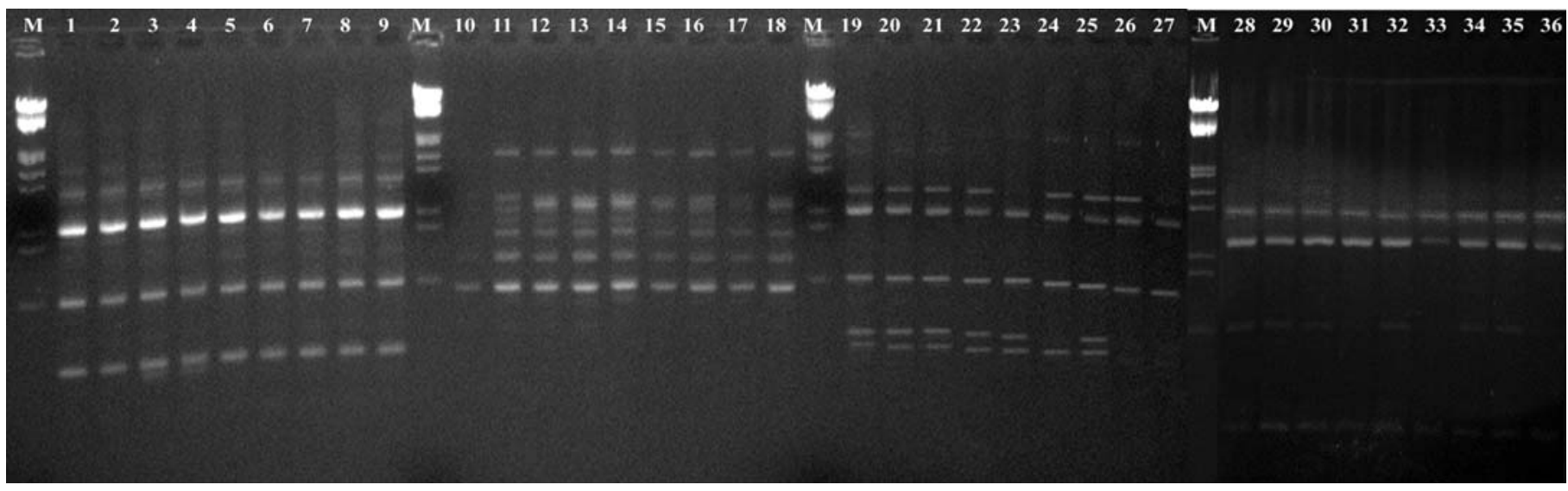

Figure 8. RAPD bands amplified by primer OPAC-01 in four Channa striatus populations collected from various Indian locations. Lane M - standard molecular weight marker; lanes 1 to 9 - Kolleru Population; lanes 10 to 18 - Periyar Population; lanes 19 to 27 - Brahamani Population and lanes 28 to 36 - Tamirabarani Population.

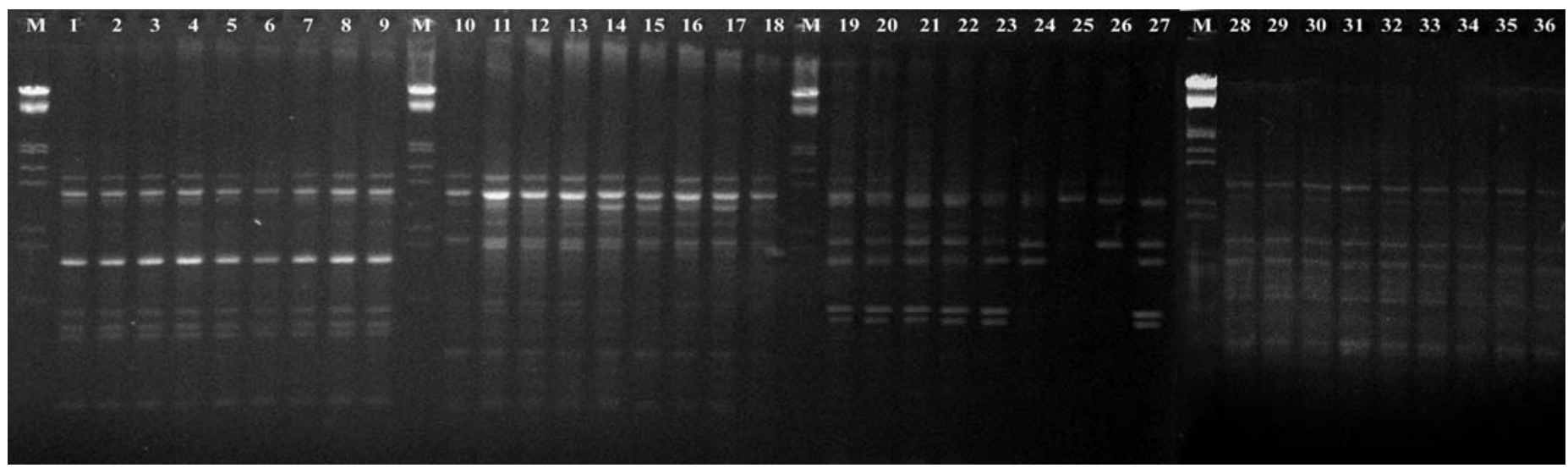

Figure 9. RAPD bands amplified by primer OPAC-03 in four Channa striatus populations collected from various Indian locations. Lane M standard molecular weight marker; lanes 1 to 9 - Kolleru population; lanes 10 to 18 - Periyar population; lanes 19 to 27 - Brahamani population and lanes 28 to 36 - Tamirabarani population. 


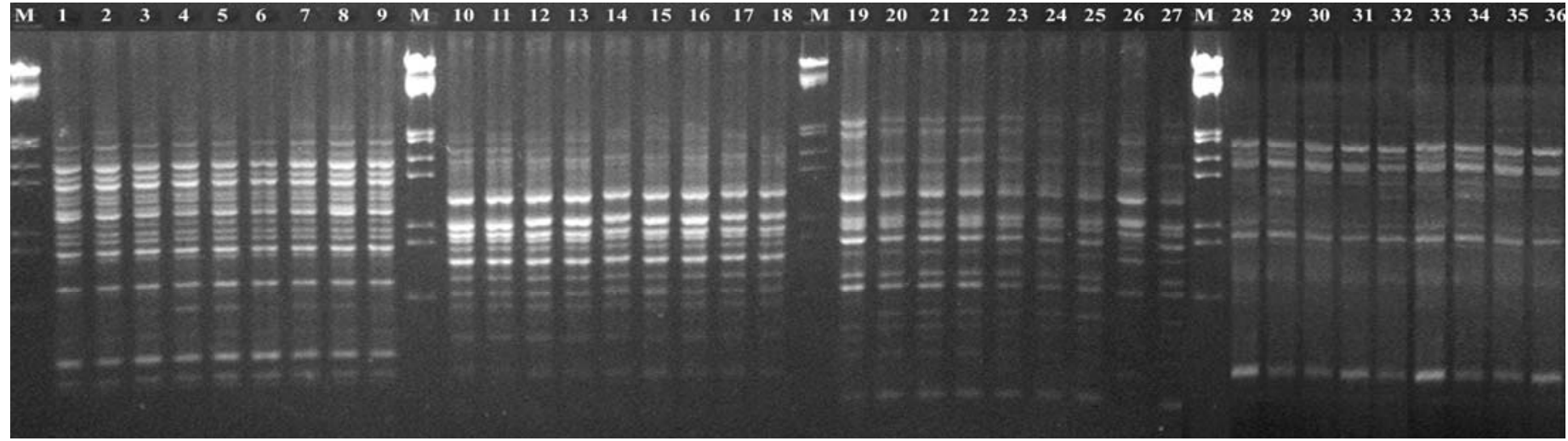

Figure 10. RAPD bands amplified by primer OPAC-05 in four Channa striatus populations collected from various Indian locations. Lane M standard molecular weight marker; lanes 1 to 9 - Kolleru population; lanes 10 to 18 - Periyar population; lanes 19 to 27 - Brahamani population and lanes 28 to 36 - Tamirabarani population.

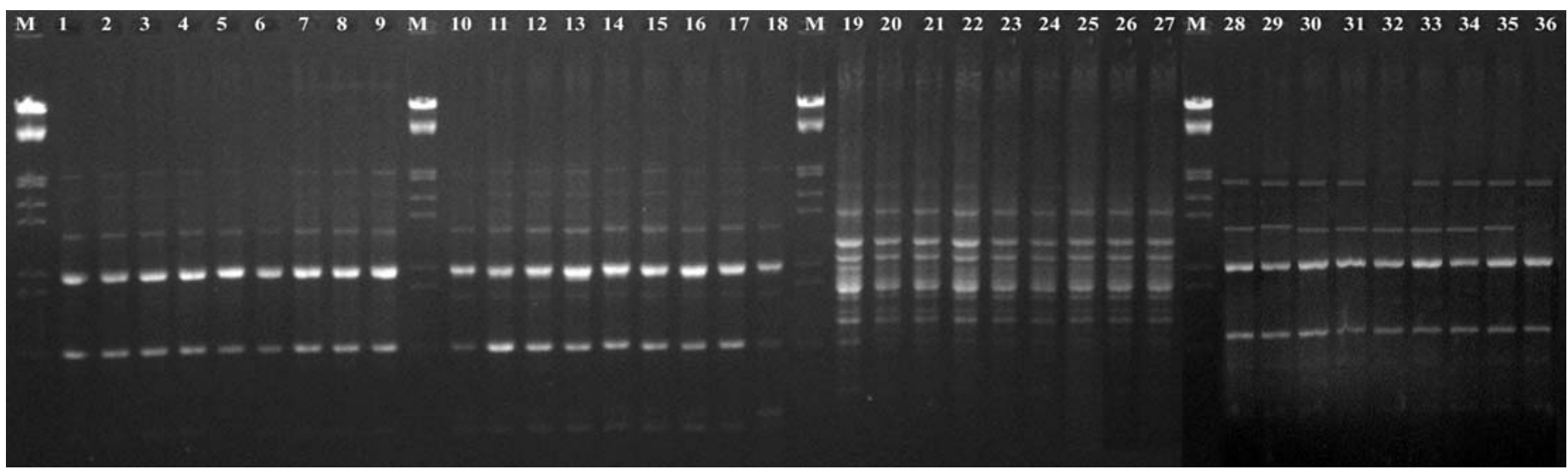

Figure 11. RAPD bands amplified by primer OPAC-07 in four Channa striatus populations collected from various Indian locations. Lane M standard molecular weight marker; lanes 1 to 9 - Kolleru population; lanes 10 to 18 - Periyar population; lanes 19 to 27 - Brahamani population and lanes 28 to 36 - Tamirabarani population.

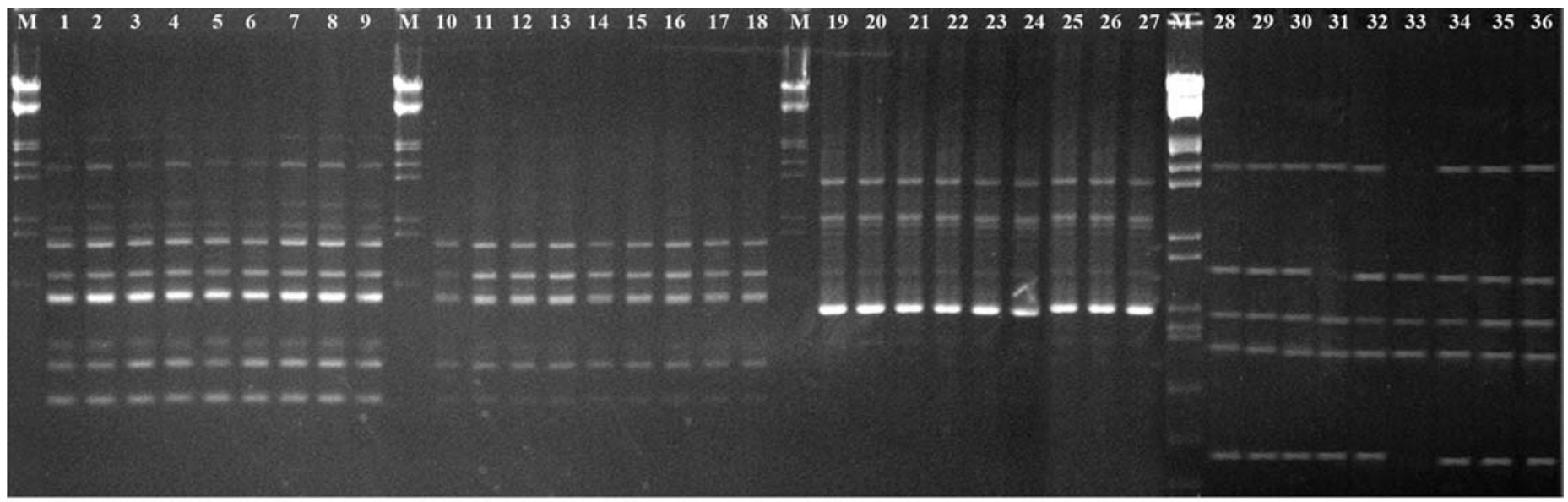

Figure 12. RAPD bands amplified by primer OPAC-09 in four Channa striatus populations collected from various Indian locations. Lane M standard molecular weight marker; lanes 1 to 9 - Kolleru population; lanes 10 to 18 - Periyar population; lanes 19 to 27 - Brahamani population and lanes 28 to 36 - Tamirabarani population. 


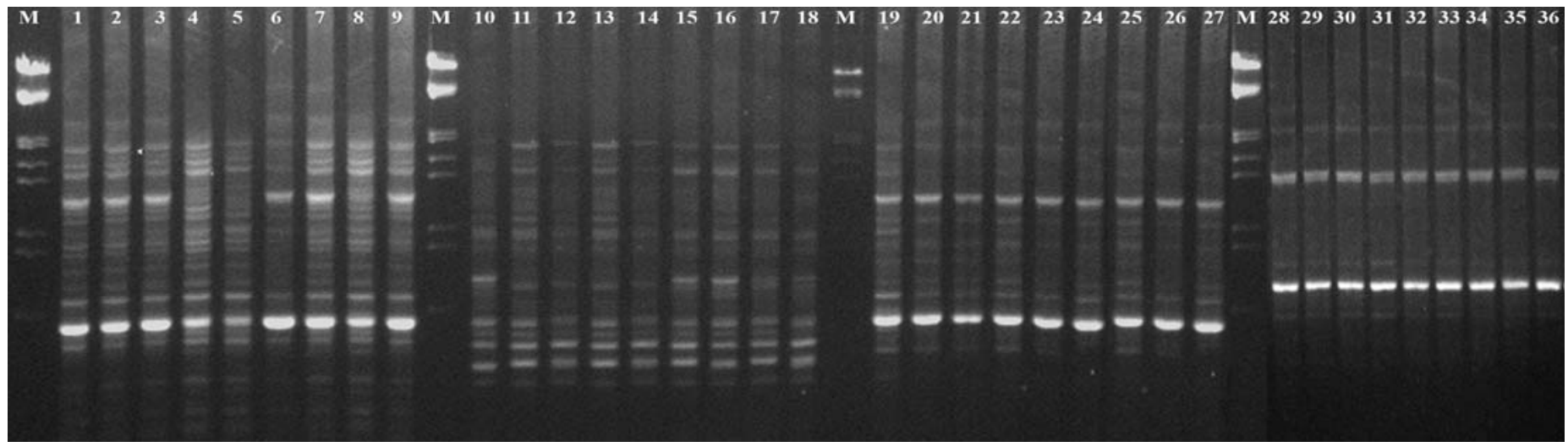

Figure 13. RAPD bands amplified by primer OPAC-19 in four Channa striatus populations collected from various Indian locations. Lane M standard molecular weight marker; lanes 1 to 9 - Kolleru population; lanes 10 to 18 - Periyar population; lanes 19 to 27 - Brahamani population and lanes 28 to 36 - Tamirabarani population.

Table 1. Performance of operon random primers on four $C$. striatus populations.

\begin{tabular}{|c|c|c|c|c|c|c|c|c|}
\hline \multirow[b]{2}{*}{$\begin{array}{l}\text { Primer } \\
\text { code }\end{array}$} & \multirow{2}{*}{$\begin{array}{c}\text { No. of } \\
\text { band }\end{array}$} & \multirow{2}{*}{$\begin{array}{l}\text { Polymorphic } \\
\text { band }\end{array}$} & \multirow{2}{*}{$\begin{array}{c}\text { Unique } \\
\text { band }\end{array}$} & \multirow{2}{*}{$\begin{array}{c}\text { Polymorphism } \\
\text { (\%) }\end{array}$} & \multicolumn{4}{|c|}{ Description of unique/population specific bands (bp) } \\
\hline & & & & & Kolleru & Periyar & Brahmani & $\begin{array}{c}\text { Tamira- b } \\
\text { arani }\end{array}$ \\
\hline OPA 10 & 13 & 11 & 2 & 84.62 & & $1(790)$ & $1(3530)$ & - \\
\hline OPA 11 & 10 & 9 & 1 & 90.0 & - & - & (1375) & - \\
\hline OPA15 & 8 & 7 & 1 & 87.50 & & (860) & - & - \\
\hline OPAC 01 & 5 & 4 & 1 & 80.00 & $(1950)$ & - & - & - \\
\hline OPAC 03 & 9 & 8 & 1 & 88.89 & $(376)$ & - & - & - \\
\hline OPAC 05 & 8 & 7 & 1 & 87.50 & - & - & - & $(1820)$ \\
\hline OPAC 07 & 13 & 12 & 1 & 92.31 & - & - & $(2102)$ & - \\
\hline OPAC 09 & 9 & 8 & 1 & 88.89 & & - & (947) & - \\
\hline OPAC 19 & 12 & 11 & 1 & 91.67 & (1716) & - & & - \\
\hline
\end{tabular}

population had two bands, Brahmani population had four bands whereas the Tamirabarani population had only one population specific band.

The polymorphic and unique DNA bands can be used as genetic markers to select the breeders from the desired population for the purpose of selective breeding programmes and to monitor the level of DNA variability in the wild or cultured population. Taking into account the amplification results of the individual primers used in the present study especially the population specific bands OPA-10 amplified single unique band for each of the population of Periyar and Brahmani waterbodies, whereas OPA-11 amplified a single unique band for Brahmani population and OPA-15 oligodecamer amplified a single unique band for periyar population. The primers OPAC -01 and OPAC -03 each amplified one specific band for Kolleru population. OPAC-05 oligodecamer amplified single unique band for Tamirabarani and OPAC-07 amplified single unique band for Brahmani population. OPAC-09 oligodecamer amplified single unique band for Brahmani population whereas OPAC-19 oligodecamer amplified a single unique bands for Kolleru population.

The overall estimate of gene diversity, average pair wise similarity index, number of polymorphic loci and percentage of polymorphism in C. striatus populations is given in Table 2. Estimates of $\mathrm{Nei}$ (1978) unbiased genetic distance (D) demonstrated the genetic distance to discriminate the different $C$. striatus populations (Table 3 ) and the values ranged from 0.3242-0.6320. UPGMA dendrogram constructed on the basis of genetic distance revealed that the genetic relationship was very close among C. striatus populations of Tamirabarani (Tamilnadu) and Periayr (Kerala). Both these populations were found to be genetically closer to Kolleru (Andhra Pradesh) population whereas C. striatus population of Brahmani (Orissa) was found to be genetically distant from the rest of the populations (Figure 14).

The presence of variability among populations as well as individuals within a population is essential for their ability to survive and successfully respond to environmental changes (Ryman et al., 1995). Excessive exploitation by capture fishery and loss of aquatic ecosystems combined with poor fishery management result in the 
Table 2. Overall estimate of gene diversity, average pair wise similarity index, polymorphic loci and percentage of polymorphism in Channa striatus populations.

\begin{tabular}{lcccc}
\hline Parameter & Kolleru & Periyar & Brahmani & Tamirabarani \\
\hline Gene diversity & 0.0684 & 0.1005 & 0.1465 & 0.0969 \\
Shannon information index & 0.0972 & 0.1426 & 0.2063 & 0.1368 \\
No. of polymorphic loci & 13 & 19 & 27 & 18 \\
Percentage polymorphism & 14.94 & 21.84 & 31.03 & 20.69 \\
\hline
\end{tabular}

Table 3. Nei's 1978 genetic distance among four populations of $C$. striatus.

\begin{tabular}{lcccc}
\hline Population ID & Kolleru & Periyar & Brahmani & Tamirabarani \\
\hline Kolleru & $\star \star \star \star$ & & & \\
Periyar & 0.3922 & $\star \star \star \star$ & & \\
Brahmani & 0.6320 & 0.4812 & $\star \star \star \star$ & \\
Tamirabarani & 0.4668 & 0.3242 & 0.4546 & $\star \star \star \star$ \\
\hline
\end{tabular}

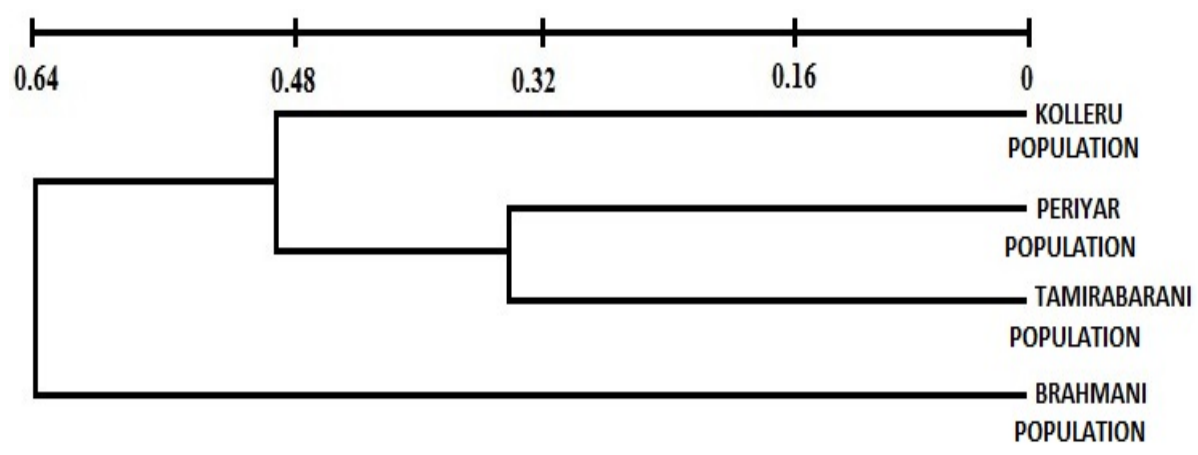

Figure 14. UPGMA dendrogram of four $C$. striatus populations based on RAPD profiles.

depletion of the fishery stocks. Such depletions can result in the loss of total gene pool (Smith et al., 1991). Conservation of the genetic diversity has emerged as one of the central issues in conservation biology (Bickham et al., 2000), considering its value for the sustainability of populations (Avise, 2004). Simultaneously, advances in molecular techniques increased the availability of different DNA-based markers, which have become efficient tools in conservation genetic studies, gene mapping, population genetics, molecular evolutionary genetics and plant and animal breeding (Haig, 1998; Ertas and Seker, 2005).

RAPD markers have been found to have a wide range of applications in gene mapping, population genetics, molecular evolution and genetic breeding programmes (Bardakci and Skibinski, 1994; Wasko et al., 2004; Leuzzi et al., 2004; Matoso et al., 2004). For instance, genetic variation has been well studied between 4 different populations of Hilsa Shad from Ganga, Yamuna, Hoogly and Narmada rivers of India using RAPD technique (Brahmane et al., 2006). Morpometric and ISSR marker systems used for categorization of five Channid species revealed the closeness of C. striatus and Channa marulius (Haniffa et al., 2014).

In the present study, the polymorphic and unique DNA bands detected can be used as genetic markers to select the breeders from the desired population for the purpose of selective breeding programmes and to monitor the level of DNA variability in the wild or cultured population of the species. Besides these, population-specific unique bands can be used to detect any possible mixing of the populations, especially during selective breeding programmes (Ferguson et al., 1995). D'Amato and Corach (1996) reported that a single RAPD fraction present in one of the two populations of Macrobrachium borellii was considered as a genetic marker for stock identification.

In the present study, based on clustering analysis of 
C. striatus populations, Tamirabarani and Periyar populations were found to be genetically closer. Among Kolleru and Brahmani populations the former was found genetically closer to Periyar and Tamirabarani populations. The population structure of freshwater organisms is dependent on the distributions of river systems (Ikeda et al., 1993; Hara et al., 1998). Among the four water bodies studied, river Tamirabarani (Tamilnadu) and Periyar (Kerala) originate from Western Ghats, South India and are geographically closer to each other than to Lake Kolleru of Andhra Pradesh. The river Brahmani (Orissa) is located more than $1500 \mathrm{~km}$ (East India) geographically away from Tamirabarni, Periyar and Kolleru lake. Based on Nei's genetic distance values, it is possible to conclude that Tamirabarni, Periyar and Kolleru populations are closer to each other when compared to Brahmani population. The genetic differentiation is primarily dependent on geographical isolation as the present study showed a significant correlation between genetic closeness and geographical distance. RAPD has been used in population studies in fisheries and can be used efficiently for variation analysis of populations with differential degrees of geographic isolation. The present study will be helpful to understand genetic relationship between different $C$. striatus populations inhabiting Indian waters, their effective management, conservation and effective scientific captive breeding programmes. The study will also be useful as the reference investigation for the future molecular as well as morphological studies on snakeheads.

\section{Conflict of Interests}

The author(s) have not declared any conflict of interests.

\section{ACKNOWLEDGEMENTS}

The authors are grateful to the Department of Science Technology (DST), New Delhi (SR/SO/AS-76/2007) for the financial assistance to carry out this work. The authors would also like to thank M/s. K. Kavitha Ramesh for her help in manuscript preparation and revision.

\section{REFERENCES}

Bhat AA, Haniffa MA, Divya PR, Gopalakrishnan A, James Milton M, Raj Kumar, Bilal Ahmad Paray (2012). Molecular characterization of eight Indian Snakehead species (Pisces: Perciformes Channidae) using RAPD markers. Mol. Bio. Rep. 39(4):4267-4273.

Ali AB (1999). Aspects of the reproductive biology of female snakehead (Channa striata Bloch) obtained from irrigated rice agroecosystem, Malaysia. Hydrobiologia. 411:71-77.

Almeida FS, Fungaro MHP, Sodré LMK (2001). RAPD and isoenzyme analysis of genetic variability in three allied species of catfish (Siluriformes, Pimelodidae) from the Tibagi river, Brazil. J. Zool. 253:113-120.
Almeida FS, Sodré LMK, Contel EPB (2003). Population structure of Pimelodus maculatus (Pisces, Siluriformes) from the Tietê and Paranapanema rivers (Brazil).Genet. Mol. Biol. 26(3):301-305.

Avise JC (2004). Molecular Markers, Natural History and Evolution. 2nd ed., Sinauer Associates, Sunderland. pp. 1-54, 115-158.

Bardakci F, Skibinski DOF (1994). Application of the RAPD technique in Tilapia Fish: Species and Subspecies identification. Heredity 73:117123.

Benziger A, Philip S, Raghavan R, Anvar Ali PH, Sukumaran M, Tharian JC, Dahanukar N, Baby F, Peter R, Rema Devi K, Radhakrishnan KV, Haniffa MA, Britz R, Antunes A (2011). Unravelling a 146 years Old Taxonomic Puzzle: Validation of Malabar Snakehead, Speciesstatus and its relevance for Channid Systematics and Evolution. PLoSONE 6(6) : e21272. doi:10.1371/journal.pone 0021272.

Berra TM (2007). Freshwater Fish Distribution, University of Chicago Press,Chicago. p.615.

Bickham JW, Sandhu S, Hebert PDN, Chickhi L, Athwal R (2000). Effects of Chemical Contaminants on Gdiversity in Natural Populations: Implications for Biomonitoring and Ecotoxicology. Mutat. Res. 463:33-51.

Bloch ME (1793). Naturgeschichte der Auslandischen fische. 7, Berlin, Germany, Morino and Co p.7,1-xiv+1-144,pls.325-360.

Brahmane MP, Das MK, Singh MR, Sugunan VV, Mukharnmjee A, Singh SN, Prakash S, Maurye P, Hajra A (2006). Use of RAPD Fingerprinting for the Delineating Populations of Hilsa shad Tenualosa ilisha (Hamilton, 1822). Genet Mol Res. 5(4):643-652.

D'Amato ME, Corach D (1996). Genetic diversity of populations of the fresh-water shrimp Macrobrachium borellii (Caridea: Palaemonidae) evaluated by RAPD analysis. J. Crustacean Biol. 16:650-655.

Dergam JA, Paiva SR, Schaeffer CE, Godinho AL, Vieira F (2002). Phylogeography and RAPD-PCR Variation in Hoplias malabaricus (Bloch, 1794). (Pisces,Teleostei) in Southeastern Brazil. Genet. Mol. Biol. 25:379-387.

Ertas HB, Seker S (2005). Isolation of Listeria monocytogenes from Fish Intestines and RAPD Analysis. Turk. J. Anim. Sci. 29:1007-1011.

Ferguson A, Taggart JB, Prodohl PA, McMeel O, Thompson C, Stone C, McGinnity P, Hynes RA (1995). The application of molecular markers to the study and conservation of fish populations, with special reference to Salmon. J. Fish Biol. 47(Suppl. A):103-126.

Hadrys H, Balick M, Schierwater B (1992). applications of random amplified polymorphic DNA (RAPD) in molecular ecology. Mol. Ecol. 1:55-63.

Haig SM (1998). Molecular contributions to conservation. Ecology 79:413-425.

Haniffa MA (2010). Indian Snakeheads. Fishing Chimes. 30(1):34-36.

Haniffa MA, James Milton M, Bilal Ahmad Paray, Bhat AA, Benzigar A (2013). Color Variation, Taxonomic Ambiguity and Synonymous Confusion a hurdle for Snakehead Conservation. Am. J. Res. Biol. 1(1):012-016.

Haniffa MA, Jeya Sheela A, Milton J, Kavitha R, Bhat AA, Abiya Chelliah (2014). Morphometric, meristic and ISSR marker systems for species identification and evolutionary analysis in five Indian Channids. Biochem. Sys. Ecol. 55:131-136.

Hara M, Sekino M, Na-Nakorn U (1998). Genetic Differentiation of Natural Populations of the Snake-head Fish Channa striatus in Thailand. Fish. Sci. 64:882-885.

Hossain MK, Latifa GA, Rahman MM (2008). Observations on Induced Breeding of Snakehead Murrel, Channa striatus (Bloch, 1793). Int. J. Sustain. Crop Prod. 3:65-68.

Ikeda M, Kijima A, Fujio Y (1993). Genetic Differentiation among local Populations of Common Freshwater Shrimp Paratya compressa improvis. Jpn. J. Genet. 68:293-302.

Leuzzi MSP, Almeida FS, Orsi ML, Sodré LMK (2004). Analysis by RAPD of the genetic structure of Astyanaxaltiparanae (Pisces, Characiformes) in Reservoirs on the Paranapanema River Brazil. Genet. Mol. Biol. 27:355-362.

Mat Jais AM, Abdul Rahim MH, Alias R, Muhammad N (2009). Genetic Marker for Haruan Channa striatus. In: Proceedings of the $8^{\text {th }}$ Malaysia Congress on Genetics. Genting Highland Malaysia. p.29.

Matoso DA, Artoni RF, Galetti Junior PM (2004). Genetic diversity of the small Characid fish Astyanax sp., and its significance for conservation. Hydrobiologia 527:223-225. 
Mitton JB (1994). Molecular Approaches to Population Biology. Annu. Rev. Ecol. Evol. Syst. 25:45-69.

Nagarajan MM, Haniffa MA, Gopalakrishnan A, Basheer VS, Abdul Muneer (2006). Genetic Variability of Channa punctatus Populations using Randomly Polymorphic DNA. Aquac. Res. 37:1151-1155.

Musikasinthorn P (1998). Channa panaw, a new channid fish from the Irrawaddy and Sittang River basins, Myanmar. Ichthyol Res. 45:355362.

Musikasinthorn P (2003). Channoidei (snakeheads) In: Hutchins M,Thoney A, Loiselle PV, Schlager N (eds) Grzimek's animal life encyclopedia, 2nd edn, vols 4, 5. Fishes I-II. Gale Group, Farmington Hills, MI, pp.437-447.

Nei M (1978). Estimation of average heterozygosity and genetic distance from amall number of individuals. Genetics. 89:583-590.

Nelson J (1994). Fishes of the World, 3rd ed. Wiley, New York, NY, p. 600.

Ruzzante DE, Taggart CT, Cook C, Goddard S (1996). Genetic differentiation between inshore and offshore atlantic cod (Gadus morhua) off Newfoundland: Microsatellite DNA variation and antifreeze level. Can. J. Fish Aquat. Sci. 53:634-645.

Ryman N, Utter F, Laikre L (1995). Protection of Intra-Specific Biodiversity of Exploited Fishes. Rev. Fish Biol. Fisher. 5: 417-446.

Saini A, Anish Dua, Vindhya Mohindra, Lakra WS (2010). Molecular discrimination of six species of Bagrid catfishes from Indus river system using randomly amplified polymorphic DNA markers. Mol. Biol. Rep. 38(5):2961-2965.

Sinh LX, Pomeroy RS (2010). Farming of Snakehead Fish (Channa micropeltes and Channa striatus) in the Mekong Delta of Vietnam. World Aquaculture, San Diego, California Abstract. p.953.

Slatkin M (1987). Gene flow and the geographic structure of natural populations. Science 236:787-792.
Smith PJ, Francis RI, Mc Veagh M (1991). Loss of Genetic Diversity due to Fishing Pressure. Fish. Res. 10:309-316.

Vishwanath W, Geethakumari KH (2009). Diagnosis and interrelationships of fishes of the genus Channa Scopoli (Teleostei: color patterns during different life stages the techniqu $e$ and Channidae) of northern. Ind. J. Threatened Taxa 1(2):97-105.

Wasko AP, Martins C, Oliveira C, Senhorini JA, Foresti F (2004). Genetic Monitoring of the Amazonian Fish Matrinchã (Brycon cephalus) using RAPD Markers: Insights into supportive breeding and conservation Program. J. Appl. Ichthyol. 20:48-52.

Williams JGK, Kubeli AR, Livak KJ, Rafalski JA, Tingey SV (1990). DNA Polymorphisms Amplified by Arbitrary Primers are useful as Genetic Markers. Nucleic Acid Res. 18:6513-6535.

Xia LI, Musikasinthorn P, Kumazawa Y (2006). Molecular phylogenetic analyses of snakeheads (Perciformes: Channidae) using Mitochondrial DNA Sequences. Ichthyological Res. 53:148.

Yeh FC, Yang RC, Boyle T (1999). POPGENE 32- Version 1.31. Population Genetics Software. Hyperlink http://www.ualberta.ca/ fyeh/popgene.pdf 